\title{
ANALISIS ZONASI UNTUK PENGELOLAAN KAWASAN PESISIR KOTA AMBON BERKELANJUTAN DENGAN MODEL SPASIAL DINAMIK
}

\author{
Pieter Th Berhitu \\ patrickberhitu@gmail.com \\ Program studi Perencanaan Wilayah dan Kota, Fakultas Teknik Unpatti
}

\begin{abstract}
Abstrak
Pembangunan kawasan pesisir dan teluk merupakan bagian terintegrasi dari pembangunan kota Ambon sehingga dalam rangka mengoptimalkan potensi wilayah teluk dan pesisir kota Ambon dan kelestarian ekosistemnya, diperlukan pengelolaan dan pemanfaatan secara terpadu dan berkelanjutan. Tujuan dari penelitian ini untuk menyusun zonasi wilayah pesisir di kota Ambon berdasarkan undang-undang zonasi dengan melihat fungsi dan peran serta kesesuaian lahan dalam menunjang keberlanjutan pengelolaan wilayah pesisir kota Ambon dan membuat model spasial dinamik untuk melihat bagaimana aspek sosial, ekonomi mempengaruhi pengelolaan kawasan pesisir berdasarkan zona pemanfaatan. Hasil análisis GIS sesuai Undang undang Zonasi berdasarkan pembobotan tingkat kerusakan dan kepentingan maka diperoleh s Zona Perlindungan Pesisir dan Pantai, serta Zona Konservasi,. Hasil GIS sesuai Undang undang Zonasi untuk tingkat kesesuaian lahan diperoleh; Tingkat kesesuaian lahan dengan skor $>80-100$, katagori $\mathrm{S}_{1}$, sangat sesuai untuk dimanfaatkan dimana daerah ini mendukung dan layak untuk dikembangkan terdapat pada 15 lokasi atau 57,69\%. Tingkat kesesuaian lahan dengan skor $\geq 60-80$, katagori $\mathrm{S}_{2}$, daerah ini sesuai untuk pemanfaatan dan layak untuk dikembangkan tapi dengan syarat tertentu sebanyak 11 lokasi atau 42,31\%. Hasil analisis Model Dinamik untuk sub model penutupan lahan kota Ambon diperoleh areal hutan diperidiksi menurun sampai 2025sekitar, 155 ha. Pemukiman bertambah 485 hektar. Model Dinamik untuk sub model Ekonomi lahan kota Ambon tercatat sektor perikanan meningkat sebesar 68 miliard lebih. Sub model sosial dan budaya diperoleh pendapatan tenaga kerja sektor perikanan juga mengalami peningkatan.sebesar menjadi 18.849.636.45 milliard, atau sekitar 24,514\% (sangat signifikan)
\end{abstract}

Kata kunci. Zonasi,pesisir, kota Ambon,berkelanjutan

\section{PENDAHULUAN}

\subsection{Latar Belakang}

Wujud Perencanaan Tata Ruang Wilayah suatu daerah secara umum dimaksudkan untuk memberikan arah dan pedoman bagi pelaksanaan pembangunan selama dua puluh tahun kedepan. Sedangkan salah satu tujuan RTRW suatu kota adalah : 1. Arahan pemanfaatan ruang wlayah kota yang berisi indikasi program utama jangka menengah lima tahunan 2. Arahan pengendalian pemanfaatan ruang wilayah kota yang berisi ketentuan umum peraturan zonasi, ketentuan perizinan, ketentuan insentif dan disinsentif, serta arahan sanksi.

Kota Ambon dengan Rencana Tata Ruang Wilayah RTRW 2011-2031 menjadi dasar dan arahan bagi meningkatkan pengendalian pemanfaatan ruang untuk menjamin efektifitas dan efisiensi kegiatan pembangunan secara berkelanjutan.

Penilitian ini bertujuan untuk 1).Memetakan potensi kawasan pesisir kota Ambon 2). Membuat model spasial dinamik untuk melihat bagaimana aspek sosial,ekonomi mempengaruhi pengelolaan kawasan pesisir berdasarkan zona pemanfaatan. 3) Menyusun zonasi wiilayah pesisir berdasarkan undang-undang dengan melihat fungsi dan peran serta kesesuaian lahan dalam menunjang keberlanjutan pengelolaan wilayah pesisir dan laut.

\section{KAJIAN TEORI DAN METODE}

2.1 Pengelolaan Wilayah Pesisir Secara Terpadu dan Berkelanjutan.

Pengelolaan wilayah pesisir secara terpadu merupakan pendekatan pengelolaan yang melibatkan dua atau lebih ekosistem, sumberdaya dan kegiatan pemanfaatan secara terpadu, agar tercapai tujuan 
pembangunan wilayah pesisir secara berkelanjutan (sustainable), sehingga keterpaduaannya mengandung tiga dimensi ; dimensi sektoral, bidang ilmu, dan keterkaitan ekologis (Dahuri et.al, 2004). Didasari kenyataan bahwa wilayah pesisir terdiri dari sistem sosial dan alam yang terjalin secara kompleks dan dinamis, maka keterpaduan bidang ilmu mensyaratkan di dalam pengelolaan wilayah pesisir hendaknya dilaksanakan dengan pendekatan interdisiplin ilmu, yang melibatkan bidang ilmu; ekonomi, ekologi, teknik, sosiologi, hukum, dan lainnya yang terkait. Wilayah pesisir terdiri dari berbagai ekosiostem (mangrove, terumbu karang, lamun, estuaria dan lainlain) yang saling terkait satu sama lain, disamping itu wilayah ini juga dipengaruhi oleh berbagai kegiatan manusia, proses-proses alamiah yang terdapat di lahan atas (upland areas) maupun laut lepas, kondisi ini mensyaratkan bahwa Pengelolaan Wilayah Pesisir dan Lautan Secara Terpadu (PWPLT) harus memperhatikan keterkaitan ekologis tersebut.

\subsection{Zonasi Berdasarkan Undang-Undang No. 26 Tahun 2007 tentang Penataan Ruang}

Berdasarkan Undang-Undang No. 26 tahun 2007 tentang Penataan Ruang zonasi untuk wilayah pesisir dipilah menjadi tiga zona yaitu zona preservasi, zona konservasi, dan zona pemanfaatan. Pembagian zona ini didasarkan pada fungsi dan peran kawasan dimana untuk kawasan yang difungsikan untuk perlindungan dan sempadan pantai dimasukkan dalam kategori kawasan dengan pola lindung, dalam hal ini zona 1 dan 2 termasuk dalam pola kawasan lindung sedangkan zona yang nanti akan akan dimanfaatkan untuk kegiatan penunjang seperti aktivitas yang ada pada kawasan pesisir disebut kawasan dengan pola budidaya dalam hal ini zona 3 termasuk dalam pola kawasan budidaya.

Proses Skoring terhadap kriteria fisik pesisir untuk menentukan zonasi dari kesesuaian lahan didasarkan pada SK Mentan No.837/KPTS/UM/11/1980 dan No.683/KPTS/UM/8/1981 (masih bisa digunakan karena belum ada ketentuan baru setelah ini), dengan karakter fisik yang diambil meliputi topografi, jenis tanah dan curah hujan. Berikut skor dan penilaian fungsi disajikan dalam Tabel 1
Tabel .1 Skor dan Penilaian Fungsi Kawasan

\begin{tabular}{llc}
\hline No & \multicolumn{1}{c}{ Fungsi Kawasan } & Total Nilai Skor \\
\hline 1 & Kawasan Lindung & $>175$ \\
\hline 2 & Kawasan Penyangga & $125-174$ \\
\hline 3 & $\begin{array}{l}\text { Kawasan Budidaya } \\
\text { Tanaman Tahunan }\end{array}$ & $<125$ \\
\hline 4 & $\begin{array}{l}\text { Kawasan Budidaya } \\
\text { Tanaman Musiman }\end{array}$ & $<125$ \\
\hline 5 & Kawasan Pemukiman & $<125$ \\
\hline
\end{tabular}

Untuk karakteristik fisik topografi kelas lereng dapat dideskripsikan nilai skornya sebagai berikut;

Tabel 2, Kelas Lereng dan Nilai Skor

\begin{tabular}{l|c|l|l|r}
\hline No & Kelas & & Deskripsi & Skor \\
\hline 1 & I & $0-8$ & Datar & 20 \\
\hline 2 & II & $8-15$ & Landai & 40 \\
\hline 3 & III & $15-$ & $\begin{array}{l}\text { Agak } \\
\text { Curam }\end{array}$ & 60 \\
\hline 4 & IV & $24-$ & Curam & 80 \\
\hline 5 & V & $>45$ & $\begin{array}{l}\text { Sangat } \\
\text { Curam }\end{array}$ & 100 \\
\hline
\end{tabular}

\subsection{Zonasi Berdasarkan Undang-Undang No. 7 Tahun 2004 tentang Sumber Daya Air}

Zonasi pada kebijakan ini di bentuk berdasarkan kriteria lahan kritis pantai berdasarkan tingkat erosi, produktivitas lahan, penutupan lahan, hidrologi dan penggunaan lahan oleh masyarakat.

Kerusakan daerah Pesisir dalam hal ini yang akan ditinjau adalah berupa : a. Pengurangan daerah pesisir; b. Sedimentasi dan pendangkalan muara.c. Kerusakan lingkungan pesisir yang terdiri atas; Erosi, Abrasi, Sedimentasi, Kerusakan lingkungan, dan bangunan bermasalah. Pembobotan tingkat kerusakan dapat digambarkan sebagai berikut;

Tabel 3. Bobot Tingkat Kerusakan

\begin{tabular}{llccc}
\hline No & Tingkat & \multicolumn{3}{c}{ Bobot Kerusakan } \\
& Kerusakan & $\begin{array}{c}\text { Erosi } \\
\text { Abrasi }\end{array}$ & Sedimentasi & $\begin{array}{c}\text { Kerusakan } \\
\text { Lingkungan }\end{array}$ \\
\hline 1 & R (Ringan) & 50 & 25 & 50 \\
2 & S (Sedang) & 100 & 50 & 100 \\
3 & B (Berat) & 150 & 75 & 150 \\
4 & AB (Amat & 200 & 100 & 200 \\
& berat) & & & \\
5 & ASB(Amat & 250 & 125 & 250 \\
& Sangat & & & \\
& Berat) & &
\end{tabular}




\subsection{Zonasi Berdasarkan Undang-Undang No. 1 Tahun 2014 tentang Pengelolaan Wilayah Pesisir dan Pulau - Pulau Kecil \\ RZWP-3-K merupakan arahan pemanfaatan} sumber daya di Wilayah Pesisir dan Pulau-Pulau Kecil pemerintah provinsi dan/atau pemerintah kabupaten/kota.. Perencanaan RZWP-3-K dilakukan dengan mempertimbangkan: a. keserasian, keselarasan, dan keseimbangan dengan daya dukung ekosistem, fungsi pemanfaatan dan fungsi perlindungan, dimensi ruang dan waktu, dimensi teknologi dan sosial budaya, serta fungsi pertahanan dan keamanan; $b$. keterpaduan pemanfaatan berbagai jenis sumber daya,fungsi, estetika lingkungan, dan kualitas lahan pesisir; dan c. kewajiban untuk mengalokasikan ruang dan akses Masyarakat dalam pemanfaatan Wilayah Pesisir dan PulauPulau Kecil yang mempunyai fungsi sosial dan ekonomi.

\subsection{Konsep Sistem Dinamik Dan Spasial Dinamik}

Sistem dinamik merupakan sebuah pendekatan yang menyeluruh dan terpadu, yang mampu enyederhanakan masalah yang rumit tanpa kehilangan esensi atau unsur utama dari obyek yang menjadi perhatian (Muhamadi, 2001).

Validasi model sistem dinamik pada dasarnya adalah suatu proses membangun kepercayaan pada kegunaan model sebagai alat bantu analisis dan perancangan kebijakan. terhadap perilaku model terhadap berbagai rekomendasi kebijakan. Tahap analisis sensivitas dan Analisis kebijakan.. Pengkajian dalam pendekatan sistem seyogyanya memenuhi tiga karakteristik,yaitu: (1) kompleks, dimana interaksi antar elemen cukup rumit; (2) dinamis, dalam arti faktor yang terlibat ada yang berubah menurut waktu dan ada pendugaan ke masa depan; dan (3) probabilistik, yaitu diperlukannya fungsi peluang dalam inferensi kesimpulan maupun rekomendasi (Eriyatno 1999)

\subsection{Metode}

Metode yang digunakan dalam penelitian ini adalah metode deskriptif kualitatif dan kuantitatif. Penelitian ini akan dilaksanakan selama 8 bulan dari bulan April - November 2017. Lokasi penelitian pada kawasan pesisir kota Ambon pada 4 kecamatan (Lihat Gambar 1)

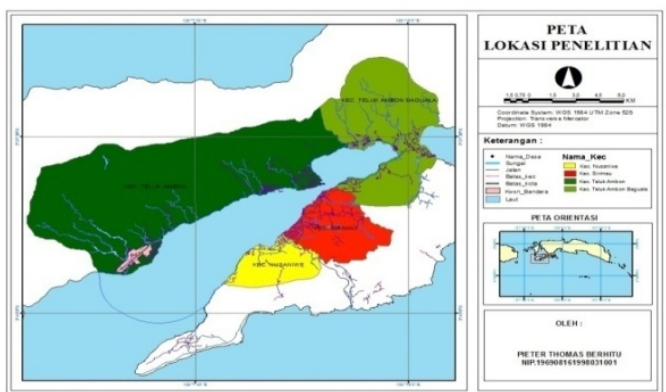

Gambar 1. Lokasi Penelitian

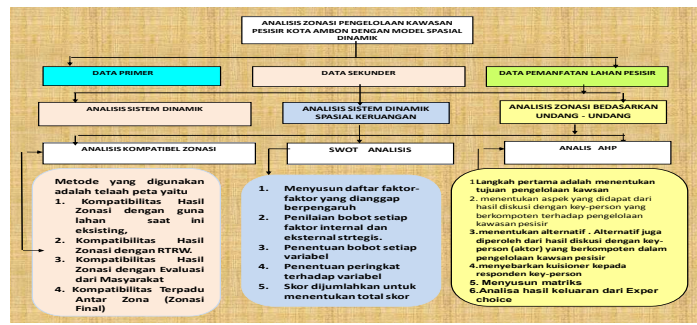

Gambar 2. Analalisis Penelitian

\section{HASIL DAN PEMBAHASAN}

\subsection{Hasil Analisis Zonasi Berdasarkan Undang-Undang No 26 Tahun 2007 Tentang Penataan Ruang}

Dari peta hasil overlay UU No 26 Tahun 2007 maka diperoleh zona kesesuaian lahan, dimana skor $<125$ adalah fungsi budidaya, skor $=125-$ 175 adalah fungsi penyangga dan skor $>175$ adalah fungsi lindung. Dari gambar 58 dapat dilihat hasil overlay yang menggambarkan zonasi kesesuaian lahan dalam bentuk tampilan peta, untuk zona budidaya ditunjukan dengan warna kuning, zona lindung dengan warna hijau dan zona penyangga dengan warna merah. Diperoleh luas lahan untuk Kawasan Budidaya 6.639,488 $\mathrm{Ha}\left(66.395 \mathrm{~km}^{2}\right)$, dan Luas lahan untuk Kawasan Lindung 13.055,23 $\mathrm{Ha}\left(130,55 \mathrm{~km}^{2}\right)$, untuk kawasan Penyangga 16.250,28 ha $(162,50$ $\mathrm{km}^{2}$ ). lihat Gambar 3

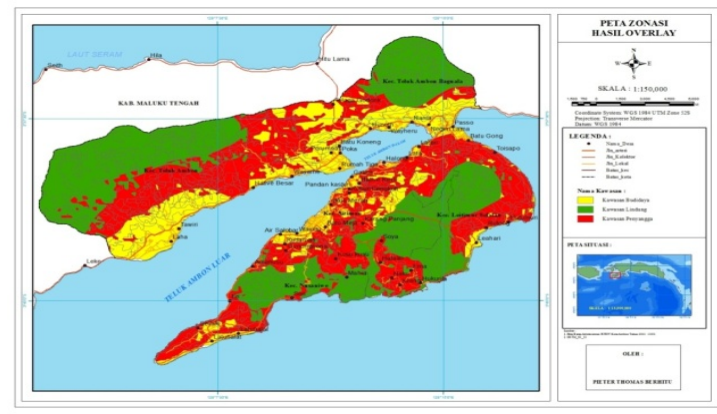

Gambar 3. Peta Zonasi UU No 26 Tahun 2007 


\subsection{Hasil Analisis Kesesuaian Lahan berdasarkan Undang-undang No 7 Tahun 2004 .}

Dari pembobotan tingkat Kerusakan dan Kepentingan untuk menentukan prioritas penanganan maka dapat diperoleh pemetaan zonasi pesisir, dengan rincian sebagai berikut; Daerah dengan nilai $>500$ : Zona Perlindungan Pesisir dan Pantai; daerah dengan nilai 300 - 499 adalah Zona Konservasi, daerah dengan nilai < 300 : Zona Pemanfaatan.

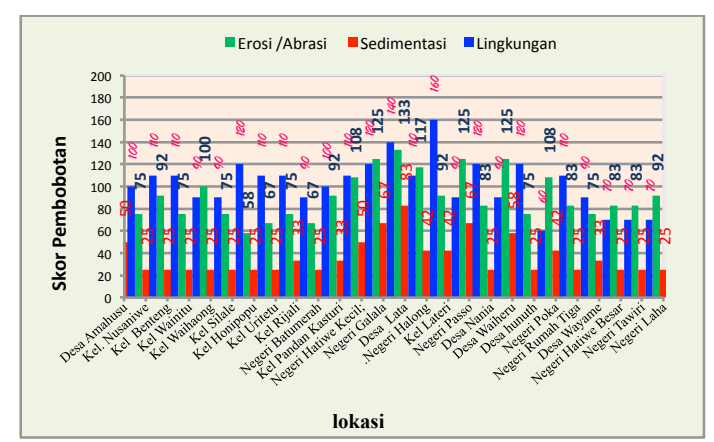

Gambar 4. Tingkat Skor Kerusakan

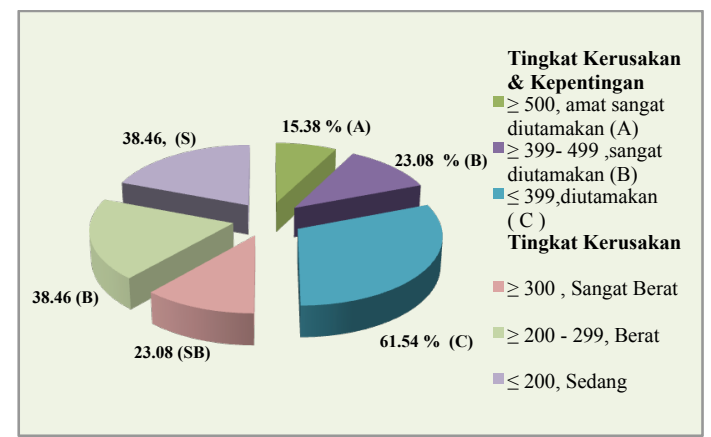

Gambar 5 Pembobotan T Kerusakan dan Kepentingan

Tingkat kerusakan untuk lingkungan tertinggi dengan skor 140 berada pada desa/negeri Galala dan terendah dengan skor 60 pada desa Hunuth. Tercatat bahwa kerusakan lingkungan dengan skor $\geq 100$ katagori "sedang sampai amat berat" sebanyak 15 lokasi atau $57.69 \%$, dan skor $<100$ katagori "ringan sampai sedang" sebanyak 11 lokasi atau 42,307 \%. (lihat Gbr 4). diperoleh nilai skor yang tertinggi adalah 512 terdapat pada desa/negeri Passo, dengan status "amat sangat diutamakan" untuk ditangani dengan level A. Sedangkan yang paling rendah dengan nilai 335 status "diutamakan" dengan level C terdapat pada desa Hunuth. Hasil pembobotan tingkat kerusakan dan kepentingan dengan skor nilai $\geq$ 500 sebanyak 4 lokasi desa/negeri/kelurahan atau
$15,384 \%$ berada pada status "amat sangat diutamakan" dengan level A
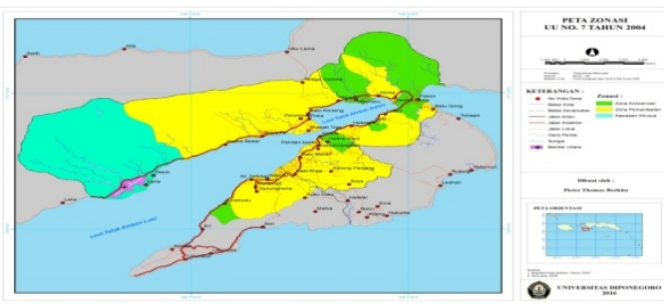

Gambar 6. Peta Zonasi UU 7 Tahun 2004

\subsection{Hasil Analisis Keses $r^{-\cdots}$, ahan Berdasarkan UU. No 1 I allun 2014 Tentang Pengelolaan Kawasan Pesisir dan Pulau Kecil}

Untuk melakukan zonasi terlebih dahulu dikaji fungsi dan peran kawasan sesuai dengan rencana tata ruang. Zonasi sesuai UU ini di fokuskan pada zona lindung dan budidaya yang secara teknis diatur dalam pedoman penataan ruang wilayah pesisir dari Kepmen No 34 tahun 2002. Zona lindung berdasarkan undang-undang pesisir diarahkan kepada daerah yang mempunyai fungsi perlindungan antara lain kawasan strategis nasional, kawasan konservasi dan kawasan preservasi pantai. Beberapa kriteria yang dapat digunakan dalam penentuan kesesuain zona pemanfaatan ruang antara lain untuk beberapa daerah seperti sempadan pantai, kawasan rawan bencana, pemukiman dan dinamika pantai. Dari skor tersebut dikalikan dengan bobot skor dengan rumus : $\mathrm{N}=($ Skor Lindung $\mathrm{x} 10 \%)+$ (Skor Pemanfaatan x 60\%) + (Skor Khusus x 30 $\%)$

Berdasarkan Gambar 5,6 dibawah ini mengambarkan tentang sebaran wilayah mewakili 4 kecamatan yang danalisis berdasarkan zonasi Undang-Undang No 1 Tahun 2014

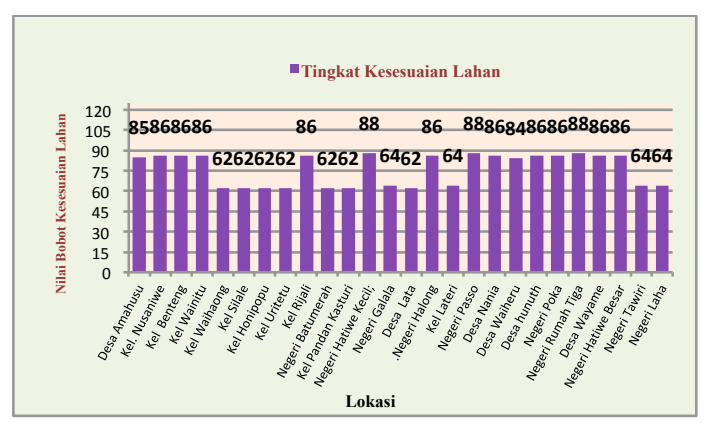

Gambar 7 Tingkat Kesesuaian Lahan 


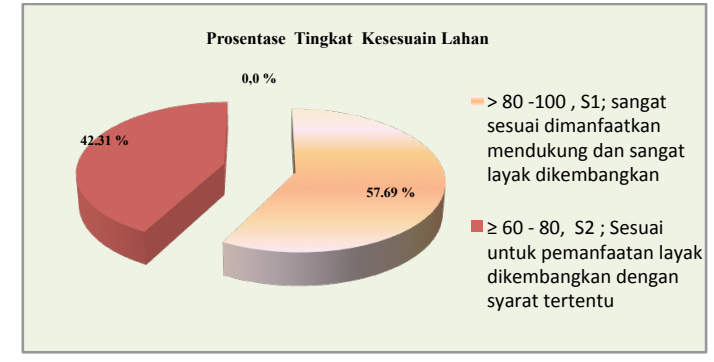

Gambar 8. Prosentase Tingkat Kesesuian Lahan

Dari Gambar 7 dan 8 diapat dilihat tingkat kesesuaian lahan dengan skor $>80-100$, katagori $\mathrm{S}_{1}$, sangat sesuai untuk dimanfaatkan dimana daerah ini mendukung dan layak untuk dikembangkan sebanyak 15 lokasi atau 57,69 \%, terdapat pada lokasi; Desa Amahusu, Kel Nusaniwe, Kel Benteng , Kelurahan Wainitu, Kelurahan Rijali, Negeri Hatiwe Kecil, Negeri Passo, Nania, Waiheru, Hunuth, Negeri Rumah Tiga, Desa Wayame, Negeri Hatiwe Kecil.

Tingkat kesesuaian lahan dengan skor $\geq 60-80$, katagori $S_{2}$, daerah ini sesuai untuk pemanfaatan Layak untuk dikembangkan tapi dengan syarat tertentu sebanyak 11 lokasi atau 42,31\%. Terdapat pada lokasi; Kelurahan Waihayong, Kelurahan Silale, Kelurahan Uritetu, Kelurahan Hunipopu, Negeri Batumerah, Kelurahan Pandan Kasturi, Desa Galala, Desa Lata , Kel Lateri, Negeri Tawiri dan Negeri Laha.
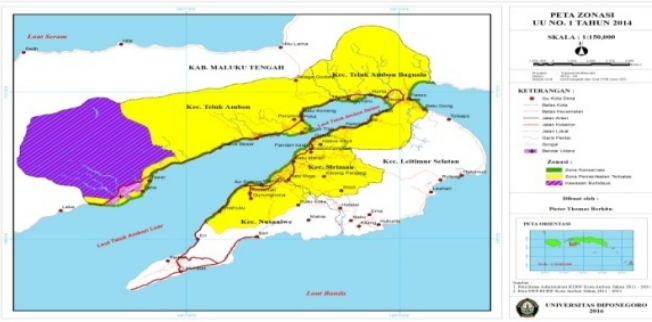

Gambar 9. Peta Zonasi UU No 1 Tahun 2014

\subsection{Hasil Pemodelan Sistem Dinamik Pemanfaatan Lahan Kota Ambon}

Model sistim yang dibangun bertujuan untuk mengabstraksikan model pengelolaan dan pemanfaatan lahan kawasan pesisir yang terdapat di kota Ambon

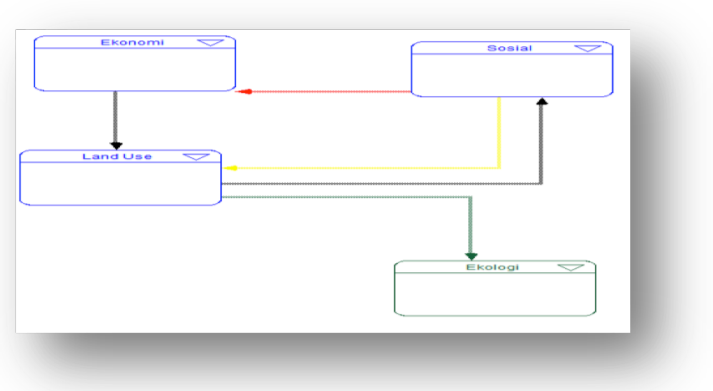

Gambar 8. Sistim Model Penggunaan lahan

\subsubsection{Sub Model Perubahan Penggunaan Lahan}

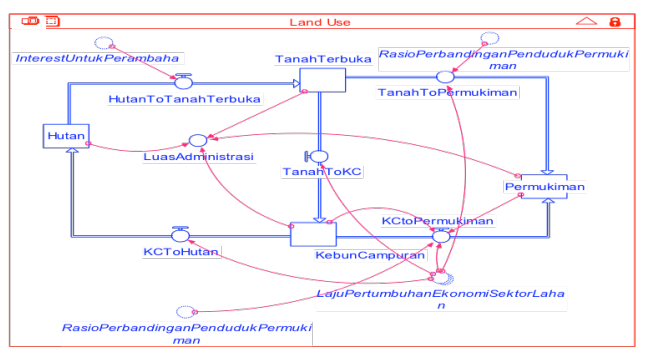

Hasil simulasi model memperlihatkan Tanah terbuka mengalami penurunan luasan sejak tahun 2005 - 2016, yakni 11 tahun sebesar 94 hektar, Prediksi sampai tahun 2025 penurunan luasan tanah terbuka sebesar 159 hektar. Kebun campuran mengalami penurunan luasan sejak tahun 2005 sampai 2016, sebesar 184 hektar. Prediksi sampai tahun 2025, penurunan luasan kebun campuran sebesar 301 hektar. Pemukiman mengalami tambahan luasan dari tahun 2005 sampai 2016, yaitu selama 11 tahun sebesar 355 hektar. Prediksi sampai tahun 2025, areal pemukiman bertambah sebesar 485 hektar. 


\begin{tabular}{cccrc}
\hline \multirow{2}{*}{ Tahun } & \multicolumn{4}{c}{ Tipe Tutupan Lahan } \\
& Hutan & $\begin{array}{c}\text { Tanah } \\
\text { Terbuka }\end{array}$ & Permukiman & $\begin{array}{c}\text { Kebun } \\
\text { Campuran }\end{array}$ \\
\hline $\mathbf{2 0 0 5}$ & $14,839.00$ & $1,540.00$ & $1,852.00$ & $10,624.00$ \\
$\mathbf{2 0 0 6}$ & $14,831.84$ & $1,531.51$ & $1,884.34$ & $10,607.31$ \\
$\mathbf{2 0 0 7}$ & $14,824.68$ & $1,523.02$ & $1,916.67$ & $10,590.63$ \\
$\mathbf{2 0 0 8}$ & $14,817.52$ & $1,514.54$ & $1,949.01$ & $10,573.94$ \\
$\mathbf{2 0 0 9}$ & $14,810.36$ & $1,506.05$ & $1,981.34$ & $10,557.25$ \\
$\mathbf{2 0 1 0}$ & $14,803.20$ & $1,497.56$ & $2,013.68$ & $10,540.56$ \\
$\mathbf{2 0 1 1}$ & $14,796.04$ & $1,489.07$ & $2,046.01$ & $10,523.88$ \\
$\mathbf{2 0 1 2}$ & $14,788.88$ & $1,480.58$ & $2,078.35$ & $10,507.19$ \\
$\mathbf{2 0 1 3}$ & $14,781.72$ & $1,472.10$ & $2,110.68$ & $10,490.50$ \\
$\mathbf{2 0 1 4}$ & $14,774.56$ & $1,463.61$ & $2,143.02$ & $10,473.82$ \\
$\mathbf{2 0 1 5}$ & $14,767.40$ & $1,455.12$ & $2,175.35$ & $10,457.13$ \\
$\mathbf{2 0 1 6}$ & $14,760.24$ & $1,446.63$ & $2,207.69$ & $10,440.44$ \\
$\mathbf{2 0 1 7}$ & $14,753.08$ & $1,438.14$ & $2,240.02$ & $10,423.75$ \\
$\mathbf{2 0 1 8}$ & $14,744.49$ & $1,431.09$ & $2,272.36$ & $10,407.07$ \\
$\mathbf{2 0 1 9}$ & $14,735.90$ & $1,424.03$ & $2,304.69$ & $10,390.38$ \\
$\mathbf{2 0 2 0}$ & $14,727.30$ & $1,416.98$ & $2,337.03$ & $10,373.69$ \\
$\mathbf{2 0 2 1}$ & $14,718.71$ & $1,409.92$ & $2,369.36$ & $10,357.00$ \\
$\mathbf{2 0 2 2}$ & $14,710.12$ & $1,402.86$ & $2,401.70$ & $10,340.32$ \\
$\mathbf{2 0 2 3}$ & $14,701.53$ & $1,395.81$ & $2,434.03$ & $10,323.63$ \\
$\mathbf{2 0 2 4}$ & $14,692.94$ & $1,388.75$ & $2,466.37$ & $10,306.94$ \\
$\mathbf{2 0 2 5}$ & $14,684.34$ & $1,381.70$ & $2,498.70$ & $10,290.26$ \\
\hline & & & & \\
\hline
\end{tabular}

\section{KESIMPULAN}

Hasil análisis GIS sesuai Undang undang Zonasi berdasarkan Bobot tingkat kerusakan dan kepentingan maka dapat dibagi Zona Perlindungan Pesisir terdapa 3 desa skor $>500$ level A. Zona Konservasi skor $<500$ terdapat 2 kelurahan dan 3 desa level B, Zona pemanafaatan skor $<400$ terdapat 4 kelurahan level C. Tingkat kesesuaian lahan dengan skor $>80-100$, katagori $\mathrm{S}_{1}$, terdapat pada 15 lokasi atau 57,69 $\%$, Tingkat kesesuaian lahan dengan skor $\geq 60$ 80 , katagori $\mathrm{S}_{2}$, sebanyak 11 lokasi atau $42,31 \%$. Hasil Model Dinamik diperoleh Pemukiman mengalami tambahan luasan dari tahun 2005 sampai 2016, yaitu selama 11 tahun sebesar 355 hektar. Prediksi sampai tahun 2025, areal pemukiman bertambah sebesar 485 hektar.

\section{DAFTAR PUSTAKA}

Badan Pusat Statistik Provinsi Maluku, (2010) Maluku Dalam Angka .

Bappeda Provinsi Maluku, (2010). Rencana Strategis Wilayah Pesisir dan Laut Provinsi Maluku
Berhitu,P (2011), Pemanfaatan Citra Pengindraan Jauh Untuk Pengelolaan Wilayah Pesisir Pantai Kota Ambon Sebagai Kota Pantai, Teknologi Vol 7 No 2 Oktobert 2011, p 948-957

Berhitu, Latuny, dan Efruan, 2010, Preliminary Feasibility Study And Development Coastal Region Of Ambon City As Ambon Water Front City In Supporting Potentials And Regional Competitiveness. International Conference on Marine Technology,(Martec) BUELT Bangladesh Dacha, Desember 2010. pp 67-72

Berhitu;,P ( 2009 ); Experience Resource Managament Concept Regional Of Coastal Area And Go out To Sea Inwroughtly At Town Ambon In Suporting Area Competitiveness And Potenscy. Prosiding" Seminar Nasional Teori dan Aplikasi Teknologi Kelautan. Fakultas Teknologi Kelautan ITS Surabaya (2008), Study Friction of Function Farm Coastal area And Influence To Regional Planology of Town Ambon. International Conference on Marine Technology,(Martec), oktober 2008, Universitas Indonesia, UI, pp. 245-251

Berhitu, P. Kakisina T.J (2009) Studi Kerusakan Pantai Kota Ambon dan Kabupaten Maluku Tengah dengan Interpertasi Sistem Informasi Geografis (SIG) dan Analisis Fisik Untuk Tata Ruang Pesisir. Prosiding Seminar Nasional dan Aplikasi Teknologi Kelautan ITS 2009, ISSN 142-2332

Bhardwaj. 2007. Application of GIS technology for Coastal Zone Management: a hydrografer perspective,

Debby A. J. Selanno, E. M. Adiwilaga, R. Dahury, Ismudi. M, H. Effendi,(2007) Analisis Kualitas Air Beberapa Wilayah Sungai Dan DAS Pada Teluk Ambon Bagian Dalam, Suatu Pendekatan Pengelolaan Wilayah Pesisir Dan Laut . Ichthyos Vol. 6, No. 2, Penerbit Universitas Pattimura, Fakultas Perikanan dan Ilmu Kelautan.

Dahuri R., J. Rais, S.Ginting dan J. Sitepu, ( 2004). Pengelolaan Sumber daya Wilayah Pesisir Dan Lautan Secara Terpadu. PT Pradnya Paramita. Jakarta

Darajati W., (2004), Strategi Pengelolaan Wilayah Pesisir dan Lautan Secara Terpadu dan Berkelanjutan, Direktur Kelautan dan 
Perikanan, Bappenas, Makalah Sosialisasi Nasional MFCDP, 2-3

ESRI, 1999. GIS for School and Libraries Version 5, Environmental Research Institute. Ferdyansah , (2011). Konsep Perencanaan Kawasan pesisir, waterfront city, dikota-kota Indonesia. Jurnal Perencanaan wilayah dan kota vol 18 no 2. 23-31

Indah Karya, PT (Persero), 1993. Pembangunan Jangka Panjang Daerah Pesisir diIndonesia, Jakarta

Kakisina, T 2007, Kajian Pola Arus Di Teluk Baguala Ambon , Prosiding Seminar Nasional Teori dan Aplikasi Teknologi Kelautan, ISSN 1412 -2332, November 2007

Pemerintah Kota Ambon, (2011). Rencana Tata Ruang Wilayah Kota Ambon (RTRW), 20112031
(2009), Master Plan Ambon Water Front City, Kota Penyedia Jasa Yang Berbasis Pesisir Dan Kelautan PEMKOTAmbon

Republik Indonesia, 2007. Undang-Undang No. 26 Tahun 2007 tentang Penataan Ruang, Sekretariat Negara, Jakarta.

Republik Indonesia, 2007. Undang-Undang No. 27 Tahun 2007 tentang Pengelolaan

Pesisir dan Pulau-Pulau Kecil. Sekretariat Negara, Jakarta. 